Sustainability, environmental citizenship rights and the ongoing challenges of reshaping supranational environmental governance

\title{
Karen Morrow
}

1. Introduction - international environmental law, reaching beyond the state

The Stockholm United Nations (UN) Conference on the Human Environment in 1972 brought an unprecedented degree of coherence to the consideration of environmental issues in the international arena. ${ }^{1}$ This event was prompted in large part by (mainly developed) states ${ }^{2}$ picking up on concern about environmental degradation that had originated in the scientific community ${ }^{3}$ and subsequently swiftly gained enormous grassroots support. ${ }^{4}$ Developing states, while also active in the Stockholm process, focussed more strongly on development issues as the source of environmental ills and as the driver for international action. The Stockholm Conference saw 113 state representatives ${ }^{5}$ participate and interestingly, indicating that this area of international law in its modern incarnation was from its very genesis not to be solely the province of state-craft, 'numerous' (but significantly not enumerated) non-governmental

\footnotetext{
${ }^{1}$ There had been international law activity on a range of topics, beginning in the nineteenth century with bilateral fisheries treaties, followed by wider international agreements on migratory species conservation, see Phillipe Sands and Jacqueline Peel, Principles of international Environmental Law Cambridge ( ${ }^{\text {rd }}$ edn.), Cambridge University Press, 2012 pp23-25, but activity was both comparatively limited and sporadic.

2 See James Gustave Speth and Peter M Haas, Global Environmental Governance, Washington D.C.: Island Press, 2006 pp 56-57.

${ }^{3}$ Not least, Rachael Carson Silent Spring London: Reader's Union, 1964.

${ }^{4} \mathrm{~A}$ number of high profile environmental non-governmental organisations were founded around this time, for example, Friends of the Earth in the United States in 1969 and Friends of the Earth International in 1971, see <http://www.foe.co.uk/resource/faqs/about_foe_founded.html> accessed 30 April 2014 and Greenpeace in Canada in 1971, see. <http://www.greenpeace.org.uk/about> accessed 30 April 2014.

${ }^{5}$ See UNEP 'Report of the United Nations Conference on the Human Environment', para 13 at $<$ http://www.unep.org/Documents.Multilingual/Default.asp?DocumentID=97> accessed 04 February 2014.
} 
organization (NGO) representatives were also present. ${ }^{6}$ The Stockholm

Conference was undoubtedly important in principle, as was the parties' adoption of the Declaration of the United Nations Conference on the Human

Environment. ${ }^{7}$ This soft law document (taking a form that was, despite some commentator's reservations as to its impact and efficacy, to become particularly significant in the complex and contested environmental sphere), ${ }^{8}$ while not legally binding on signatories, represented both a crucial institutional recognition of the escalating impact of human activity of the environment ${ }^{9}$ and a statement of intent to address it. ${ }^{10}$ The ambitious scope of action that would ultimately be required to effectively engage with the anthropogenic environmental impacts, extending well beyond the habitual realm of state activity, was specifically alluded to in the preamble to the Declaration:

To achieve this environmental goal will demand the acceptance of responsibility by citizens and communities and by enterprises and institutions at every level, all sharing equitably in common efforts. Individuals in all walks of life as well as organizations in many fields, by their values and the sum of their actions, will shape the world environment of the future. ${ }^{11}$

At the same time, this visionary conception of a future human/environment relationship extends not only beyond States but also an individualistic and state-

\footnotetext{
${ }^{6} \mathrm{lbid}$ at para 17.

${ }^{7}$ At <http://www.unep.org/Documents.Multilingual/Default.asp?documentid=97\&articleid=1503> accessed 30 April 2014.

${ }^{8}$ See, for example, Pierre-Marie Dupuy, 'Soft Law and the International Law of the Environment' (1990-91) 12 Mich. J. Int'I L. 420.

${ }^{9}$ Declaration of the United Nations Conference on the Human Environment, $n$ 7, preamble, para 1 .

$10 \mathrm{lbid}$, preamble, para 6.

$11 \mathrm{lbid}$, preamble, para 7.
} 
centric conception of human rights as its sole focus; additionally it inculcates a pervasive, positive and expansive notion of human responsibility and agency that embraces not only individuals but also enfolds the human collectivities in various guises that generate environmental impacts at all levels. Nonetheless, despite this revolutionary rhetoric, the tenor of the Declaration as a whole, and the substantive principles that it embodied, were firmly focussed on the roles and responsibilities of States ${ }^{12}$ and international institutions. ${ }^{13}$ Principle 19 of the Declaration however, in recognising the importance of environmental education as: '... essential in order to broaden the basis for an enlightened opinion and responsible conduct by individuals, enterprises and communities in protecting and improving the environment ...' did go some way to acknowledging the fact that addressing environmental degradation presented societal challenges that extended beyond states as entities. Implicit too in this statement supporting 'responsible conduct' is the conceptual root of wider public participation rights as one mechanism through which to employ of such 'enlightened opinion' in the twin causes of environmental protection and improvement.

In practical terms the founding of the United Nations Environment Programme (UNEP) in the wake of the Stockholm conference ${ }^{14}$ ensured that the environment had a discrete institutional presence within the UN (albeit a relatively weak one $)^{15}$ and that environmental concerns remained on the

\footnotetext{
12 For example, ibid, para 24.

13 lbid, para 25.

14 UN General Assembly resolution 2997 (XXVII) of 15 December 1972.

15 See, for example, Richard G Tarasofsky, 'International Environmental Governance: Strengthening UNEP' 2002 at <http://archive.unu.edu/interlinkages/docs/IEG/Tarasofsky.pdf $\geq$ accessed 30 April 2014. UNEP's role was eventually
} 
international community's agenda. Nonetheless, while the Stockholm Summit undoubtedly set progress in international environmental law and policy in motion, its momentum was both slowed and truncated in relatively short order by the new complexity in global economic affairs precipitated by the oil crisis that began in 1973, which arguably pressed environmental concerns into the background. The new economic vulnerability ${ }^{16}$ experienced by developed states in this context ensured that progress was cautious, but, at the same time, it served to underline the emerging understanding of the prevalence and interconnectedness of global environmental issues and other aspects of state activity. While the 1970s in particular generated a great deal of legal activity at state and regional transnational levels, not least in the European Union (EU) ${ }^{17}$ and under the auspices of the Organization for Economic Co-operation and Development (OECD),${ }^{18}$ the global international environmental scene was relatively quiet at this time, with a few notable exceptions, such as the adoption of the Convention on International Trade in Endangered Species of Wild Fauna

\footnotetext{
somewhat enhanced following the Rio+20 Conference in 2012, see the Outcome Document, 'The Future We Want', para 88 at <http://www.uncsd2012.org/content/documents/727The\%20Future\%20We\%20Want\%2019\%20 June\%201230pm.pdf> accessed 30 April 2014. These relatively marginal enhancements however fell well short of what had been sought by those concerned at UNEP's lack of institutional muscle, see for example, Frank Biermann, 'Reforming Global Environmental Governance: The Case for a United Nations Environment Organisation' Stakeholder Forum, 2011 at <http://www.stakeholderforum.org/fileadmin/files/WEO\%20Biermann\%20FINAL.pdf> accessed 28 April 2014.

${ }^{16}$ For a broader contextual consideration of the impact of the oil crisis on international environmental law, see Sundhya Pahuja, 'Conserving the World' Resources' in James Crawford and Martti Koskenniemi (eds.), The Cambridge Companion to International Law, Cambridge, Cambridge University Press, (2012) 398-420.

17 See, for example, Ingmar von Homeyer, 'The Evolution of EU Environmental Governance' in Joanne Scott (ed.) Environmental Protection: European Law and Governance, Oxford, Oxford University Press (2009) pp1-26.

${ }^{18}$ See, for example, Iris Borowy, Defining Sustainable Development for Our Common Future: $A$ History of the World Commission on Environment and Development Earthscan/Routledge, Abingdon, (2014), pp 28-30 and 39-40.
} 
and Flora ${ }^{19}$ (CITES) in 1973. It was however only in the run-up to and at the UN Conference on Environment and Development (UNCED) in Rio in 1992 (considered below), that environmental matters regained a more dynamic species of global prominence akin to and even exceeding that which they had enjoyed in the Stockholm process. The UNCED saw 172 states participating, 108 of these at head of state/government level and 2,400 NGOs with 17,000 participants taking part in the parallel NGO forum. ${ }^{20}$

\section{The WCED, participation and the emergence of sustainable development}

The central and highly ambitious, but also complex and contested, concept of sustainable development was researched, framed and taken forward to Rio through the work of the World Commission on Environment and Development (WCED), popularly known as the Brundtland Commission, and its resulting seminal report Our Common Future. ${ }^{21}$ At the conference itself the wealth of nuanced and conceptually rich material that had been produced on sustainable development by this process was, perhaps inevitably, reduced to the pervasive and still prevalent media-friendly sound-bite of the 'Brundtland definition': '... development that meets the needs of the present, without compromising the ability of future generations to meet their own needs'. ${ }^{22}$ However, as Borowy points out in her recent comprehensive account of the work of the WCED, the

\footnotetext{
${ }^{19}$ At <http://www.cites.org/eng/disc/text.php $\geq$ accessed 09 May 2014.

${ }^{20}$ See UN Briefing Papers/The World Conferences: Developing Priorities for the 21st Century at <http://www.un.org/geninfo/bp/enviro.html> accessed 04 February 2014.

${ }^{21}$ World Commission on Environment and Development: Our Common Future, Oxford University Press, Oxford (1987) (the Brundtland Report).

22 lbid, Chapter 2 para 1.
} 
reductionist approach exhibited in the 'Brundtland definition', which has become the largely accepted orthodoxy:

... trivializes both the work of the WCED and the challenges of sustainable development, which are at the bottom of the enormous discrepancy between widespread theoretical endorsement of the concept and the near absence of its implementation. ${ }^{23}$

It is certainly the case that the flaws of the overly simplified conception of sustainable development as endorsed at Rio, not least in burying those integral yet politically unpalatable aspects of the WCED's approach that focussed on what Jim MacNeill, its Secretary General, terms: '... the need to live within nature's limits', ${ }^{24}$ have been the subject of decades of wide-ranging critique and commentary. ${ }^{25}$ In any event, it can fairly be said that the emergence of the concept of sustainable development at Rio did at least serve to place the environment, which had again become a commonly neglected policy concern at the time, on to a notionally co-equal footing with dominant economic and social matters.

In actuality and in the WCED's conception, sustainable development with its necessarily expansive socio-political, economic and environmental grounding demands nothing less than the radical re-fashioning of the relationship between

\footnotetext{
23 Borowy $\mathrm{n} 18$ at $\mathrm{p} 4$.

24 Ibid, Jim MacNeill, 'Foreword', at ix.

${ }^{25}$ See, for example, Neil K Dawe and Kenneth L Ryan 'The Faulty Three-Legged-Stool Model of Sustainable Development' Conservation Biology, 2002, 1458; Subhabrata Bobby Banerjee 'Who Sustains Whose Development? Sustainable Development and the Reinvention of Nature' Organization Studies 24(1) (2003) 143-180; Dire Tladi, Sustainable Development in International Law: An Analysis of Key Enviro-Economic Instruments, Pretoria University Law Press, Cape Town, 2007; Michael Redclift, Sustainable Development: Exploring the Contradictions Routledge/Taylor \& Francis (electronic edition 2003); and Duncan French International Law and Policy of Sustainable Development, Manchester University Press 2005.
} 
humanity and the environment. This development had been prefigured, albeit in rudimentary form in the Stockholm Declaration, as discussed above and now, having come centre-stage comprises the central concern of this chapter. The paradigm shift necessary to re-work the human/nature relationship inevitably entails engagement with societal complexity in its multifarious forms and this in turn necessitates re-envisioning the global polis and its governance. A core concern in this regard is the unprecedented, yet integrally inherent imperative in the concept of sustainable development, to draw in not only states but also communities and individuals in order to fundamentally refashion all facets of the human/nature relationship. This requires, amongst other things, supplementing the traditional 'top-down' governance model by harnessing bottomup/grassroots activity to established political processes. ${ }^{26}$ Thus, for all the many flaws in the concept of sustainable development as a whole, ${ }^{27}$ in real terms the greatest legacy wrought by the WCED and UNCED in the last two decades arguably lies in the fact that it necessitated initiating what is in principle (though admittedly as yet markedly less so in practice) a seismic shift in the nature of the global polis. This modernising development, representing the transference from government to governance, has its roots both in the inherent nature of the concept of sustainable development referred to above and in the methodology adopted by the WCED. The former intimated that, in principle, the adoption of public participation in the environmental sphere was a core element in sustainability praxis and the latter practically trialled a participatory approach. The WCED by dint of its own methodology - which saw the Commission travel

\footnotetext{
26 Our Common Future, n 21.

27 See, for example, Banerjee, n 25.
} 
the globe between 1983 and 1987 researching, developing and above all popularizing ${ }^{28}$ the concept of sustainable development - altered expectations about what can be achieved in terms of public engagement with international policy-making. Significantly, rolling out of a series of public hearings across the globe ${ }^{29}$ became an integral means of gathering the material necessary to inform the WCED's deliberations. This hands-on collection of evidence from a vast range of what would now be termed stakeholders, thus played a part in shaping not only the WCED's final report, but also in the evolution of participation in global sustainable development and environmental governance. The hearings actively invoked a conception of sustainable development praxis embracing pluralism in harnessing not only the expertise of civil society but also of local governments, scientists and other experts, business and industry. MacNeill went so far as to identify these public hearings '.. the key to our consensus...', which in turn 'was crucial to the success of our endeavours ...' 30 The public meetings certainly served to galvanise the members of the WCED, generating a sense of urgency in their deliberations by dramatizing the real-world implications of what could otherwise have been reduced to abstract issues and by demonstrating how imperative it was that they should forge a workable consensus despite their widely differing personal perspectives. ${ }^{31}$ It could also be argued that the hearings gave the WCED a much higher public profile than had been the norm for previous UN Commissions, simultaneously generating of

\footnotetext{
28 The WCED did not 'invent' sustainable development as a concept, though it did further develop it and bring it into the mainstream. See Borowy $n 18$ p3.

${ }^{29}$ These were achieved despite the fact that in some parts of the world the concept of public involvement was politically contentious or even a completely unknown quantity. Ibid, p69. 30 lbid, viii.

31 lbid, Chapters 3-9.
} 
both wider support for its activities and creating a climate of expectation as to its results. In concrete terms this would seem to be borne out in many ways and not least by the fact that Our Common Future became the most widely read UN report that had ever been produced. ${ }^{32}$

The WCED process and methodological approach not only set the scene for the UNCED, it also played a part grounding in the subsequent development of a broader international incarnation of emerging environmental citizenship, ${ }^{33}$ identified by Bell as one of the forms of 'multiple, adjectival citizenship' that was to rise again to prominence in the late twentieth century. ${ }^{34}$ This was evident in the WCED's incorporation into its core activities and resulting outputs of the idea that, while state-craft remains central to addressing our interlocking global environmental crises at a macro level, to do so effectively also requires engagement at the grass-roots/micro level. Drawing on its own methodology and resulting incarnation of the concept of sustainable development, the WCED's ultimate report therefore pointed comprehensively for the first time to the necessity of complementing the traditional, statist, 'top-down' model of international law with a new harnessing of 'bottom-up' civil society activity and uniting these in a common cause. ${ }^{35}$

\section{Civil Society and the UNCED}

\footnotetext{
32 Ibid, viii.

33 See, for example, Andrew Dobson (ed.), Environmental Citizenship, (2006) MIT Press, Cambridge MA

34 Derek R Bell ‘Liberal Environmental Citizenship’ Environmental Politics Vol. 14 Mo. 2 179-194 (2005) at 180.

35 Report of the World Commission on Environment and Development: Our Common Future (1987) at <http://conspect.nl/pdf/Our_Common_Future-Brundtland_Report_1987.pdf.> (accessed 04 December 2013), in particular Chapter 12.
} 
The perception of the need for bottom-up engagement with sustainable development was not limited to the role and activities of the WCED; in parallel to this process, civil society had been active in garnering a role for itself in the wider sustainability debate. While some contemporaneous commentators reported the role of civil society at the Rio Summit in frankly contemptuous terms,${ }^{36}$ the reality was that, behind the scenes of the colourful parallel NGO side event, and long before it in the run-up to the UNCED, serious work had been done, influence generated and results reaped. We can see a concrete example of this in the activities of women's groups in in contributing to shaping Agenda 21.

The prominent role forged for and by women in Agenda 21 did not come out of the ether and in two important respects it can be argued that in this context the door was already open to their participation. Firstly, the UN had an established history of quite extensive engagement with the complex cross-cutting issues raised by gender. ${ }^{37}$ Concomitantly the women's movement had a working knowledge of the mechanics of participating in international law and policy making processes. This history of interaction had created shared pools of institutional and civil society experience, knowledge, networks and contacts that could potentially be exploited in other contexts. Broadly speaking though, the UN's approach to gender prior to 1992 had been a top-down process (albeit

\footnotetext{
36 The Economist's Special Correspondent in Rio: 'The Green Legacy' 13 June 1992 <http://www.economist.com/node/15058218> accessed 04 February 2014.

${ }^{37}$ For a very brief graphic overview see UN Women: 'A History of Gender Balance in the United Nations'

$<$ http://www.un.org/womenwatch/uncoordination/documents/overview/unsystem/unsystemtimeli ne-infographic.pdf> accessed 28 July 2014.
} 
arguably an innovative one that was at times highly responsive to grassroots input), with intergovernmental organisations and states taking the lead in fostering first the inclusion, then the prioritisation and ultimately the mainstreaming agenda in the search for more effective policies and programmes. ${ }^{38}$ Secondly, sustainable development, while also promoted and facilitated by intergovernmental organisations and states, is as alluded to above, also necessarily predicated on grass-roots involvement, thus driving the need for engagement with stakeholder groups. Key mechanisms in facilitating the radical degree of grass-roots engagement that sustainable development requires include nurturing and developing the role of civil society, which was a feature of the WCED's working practices and was to become a central element of Agenda 21 (of which more below). ${ }^{39}$ The latter would actively cultivate the involvement of nine 'major groups' as instrumental in forging and taking forward developing the sustainability agenda. Women would be numbered among them ${ }^{40}$ undoubtedly a significant development in principle, but not a surprise, as the women's issues were already a well-established area within the UN system. ${ }^{41}$ Furthermore, and this was to prove particularly valuable in the sustainability context, in general terms the women's movement drew support

\footnotetext{
38 Karen Morrow 'Not so much a meeting of minds as a coincidence of means: Ecofeminism, gender mainstreaming and the United Nations' Thomas Jefferson Law Review, Vol. 28 No.2, (2005) pp185-204.

39 Jacklyn Cock 'The World Women's Congress for a Healthy Planet' Agenda No. 12 Rural Politics (1992) pp 63-66.

40 The others being: children and youth; indigenous peoples; NGOS; Local Authorities; workers and trade unions; business and industry; the scientific and technological community and farmers - see UN Agenda 21 at <https://docs.google.com/gview?url=http://sustainabledevelopment.un.org/content/documents/A genda21.pdf\&embedded=true > accessed 20 May 2014.

${ }^{41}$ See Hilkka Pietila: 'The Unfinished Story of Women and the United Nations' Development Dossier, United Nations Non-Governmental Liaison Service, New York and Geneva (2007) online at http://www.un-ngls.org/orf/pdf/UnfinishedStory.pdf accessed 28 July 2014, in particular chapters 2 and 4.
} 
and influence from established global grassroots networks and women also played an established role in the rank and file of grassroots environmental organisations and (to some degree) their leadership. ${ }^{42}$ These factors combined to see the women's movement excellently positioned to push its priorities to the fore in the sustainability context more generally and in Agenda 21 in particular. The most high profile initiative in this regard in the run up to the UNCED was instituted by the Women's Environment and Development Organisation (WEDO), ${ }^{43}$ a leading women's environmental NGO. It instituted the World Women's Congress for a Healthy Planet in Miami in 1991, which built on and developed existing women's networks to ensure that the broad spectrum of women's opinion from the developed and the developing world was represented in an open and inclusive participatory process. The Congress proved a significant platform for women's engagement with the new sustainability oriented strand of international environmental law and policy. In concrete terms the Congress produced its own outcome document, 'Women's Action Agenda $21,{ }^{4}$, which in turn influenced redrafting of the original supposedly 'gender neutral' draft text of Agenda 21, integrating gender issues throughout, which remain in the document as finally agreed at the UNCED itself. ${ }^{45}$

\section{The UNCED, participation and sustainable development}

\footnotetext{
${ }^{42}$ Robert R M Verchick 'In a Greener Voice: Feminist Theory and Environmental Justice' 1996 Harvard Women's Law Journal Vol. 19, 23.

${ }^{43}$ See <http://www.wedo.org/about> accessed 04 May 2014.

${ }^{44}$ At <http://www.iisd.org/women/action21.htm> accessed 31 July 2014 ..

${ }^{45}$ Karen Morrow: 'Gender, International Law and the Emergence of Environmental Citizenship' pp 33-61 in Susan Buckingham-Hatfield et al.: In the Hands of Women - Women, Human Rights and the Environment, Manchester University Press, 2006.
} 
The most prominent achievements of the UNCED, as viewed at the time and probably until their momentum faltered and they were seen as unable to keep pace with accelerating environmental degradation in the respective areas, were the adoption of a number of the high profile hard law multi-level environmental agreements (MEAs) conventions: the Framework Convention on Climate Change $^{46}$ and the Convention on Biodiversity. ${ }^{47}$ However, despite these relatively promising beginnings, on-going progress in all of these areas is at best slow and by all measures woefully inadequate as climate change ${ }^{48}$ and biodiversity depletion ${ }^{49}$ on the whole remain seemingly intractably problematic.

In real terms it is the Rio Summit's initially relatively unheralded and contemporaneously underrated soft law outcomes, notably the Rio Declaration on Environment and Development ${ }^{50}$ and its accompanying 'blueprint for sustainability' - Agenda $21,{ }^{51}$ that have arguably proved to have more significant impacts in altering our engagement with anthropogenic environmental impacts in the longer term. ${ }^{52}$ If, as suggested above, in considering the input of women's

\footnotetext{
${ }^{46} \mathrm{At}$

$<$ http://unfccc.int/files/essential_background/background_publications_htmlpdf/application/pdf/c onveng.pdf> accessed 04 February 2014.

${ }^{47}$ At <http://www.cbd.int/doc/legal/cbd-en.pdf> accessed 04 February 2014.

${ }^{48}$ See for example, IPCC 2014: Impacts, Adaptation and Vulnerability (2014) at $<$ http://www.ipcc.ch/report/ar5/wg2/> accessed 28 July 2014.

${ }^{49}$ See, for example, Stuart M. Butchart et al.: 'Global Biodiversity: Indicators of Recent Declines' 28 May 2010 Vol. 328 Science pp 1164-1168 at http://sci.odu.edu/biology/directory/Butchart\%20et\%20al\%20Global\%20biodiversity\%20declines \%20Science.pdf accessed 28 July 2014.

$50 \mathrm{At}$

$<$ http://www.unep.org/Documents.Multilingual/Default.asp?documentid=78\&articleid=1163> accessed 04 February 2014.

${ }^{51} \mathrm{At}<\mathrm{http}: / /$ sustainabledevelopment.un.org/content/documents/Agenda21.pdf> accessed 04 February 2014.

52 See, for example, Karin Bäckstrand, Karin (2006) ‘Democratising Global Environmental Governance. Stakeholder Democracy after the World Summit on Sustainable Development', European Journal of International Relations, Vol. 12, No. 4, pp. 467-498.
} 
groups into Agenda 21, ${ }^{53}$ stakeholder participation had already proved

significant in the run-up to the UNCED, its continuing significance was secured

by the status accorded to it in these summit outcomes. This line of developing

the prioritisation of participation in international environmental governance was

of course also in harmony with other more general expressions of the UN's

ethos in this regard in relation to state systems in human rights instruments. ${ }^{54}$

The Rio Declaration however instituted a significant step by placing participation

and, by necessary implication, procedural matters firmly on the international

agenda, stating in Principle 10 that:

Environmental issues are best handled with the participation of all concerned citizens, at the relevant level. At the national level, each individual shall have appropriate access to information concerning the environment that is held by public authorities, including information on hazardous materials and activities in their communities, and the opportunity to participate in decision-making processes. States shall facilitate and encourage public awareness and participation by making information widely available. Effective access to judicial and administrative proceedings, including redress and remedy, shall be provided. 55

\footnotetext{
${ }^{53}$ Some of the other major groups were also similarly well-positioned in this context and at this time, for example workers and trades unions, others faced greater challenges in exerting influence in the international stage but were rapidly gaining momentum. ${ }^{54}$ Article 21 of the Universal Declaration of Human Rights, for example, affirms the right of everyone to take part (directly or indirectly) in the government of his or her country at $<$ http://www.un.org/en/documents/udhr/> accessed 29 May 2014.

55 Principle 10, 1992 UN Declaration on Environment and Development at $<$ http://www.unep.org/Documents.Multilingual/Default.asp?documentid=78\&articleid=1163> accessed 14 October 2013.
} 
In addition to recognising the importance of participation in principle and highlighting the need for it in the formerly neglected environmental sphere, the Rio Declaration also identified the three core human rights-based elements that are essential to its realisation: access to information; participation in decisionmaking processes and access to justice. This triad of procedural participation rights was not new and has its antecedents in one form or another in most domestic legal systems - what was novel was the transplantation of longestablished human rights into a new area and ultimately extending their reach in some respects onto the international arena. In light of this it is no surprise that aspects of rights-based participation had emerged in international policy documents on sustainable development ${ }^{56}$ that effectively acted as precursors to the Rio process and outcomes; for example in the oft-cited Ministerial Declaration on Environmentally Sound and Sustainable Development in Asia and the Pacific, ${ }^{57}$ para. 27 of which affirmed:

...the right of individuals and non-governmental organizations to be informed of environmental problems relevant to them, to have the necessary access to information, and to participate in the formulation and implementation of decisions likely to affect their environment.

The trinity of participation rights invoked in the Rio Declaration however took participation to its logical conclusion - access to information and participation are not fully meaningful unless accompanied and supported by a right of legal challenge to the decisions arrived at through their use. Rio also provided a high-

\footnotetext{
${ }^{56}$ For a comprehensive account of developments in this area see Donald K Anton and Dinah L Shelton: Environmental Protection and Human Rights Cambridge, Cambridge University Press 2011.

57Bangkok, 16 October 1990, A/CONF.151/PC/38.
} 
profile focal point that served to popularize the notion of participation in the sphere of sustainability. The participation rights invoked at Rio have subsequently been described by UNEP as 'citizen's environmental rights'58 and their most famous and legally significant regional manifestation to date has been as the central planks the Aarhus Convention, ${ }^{59}$ which Kofi Annan has described as '... the most ambitious venture in environmental democracy undertaken under the auspices of the United Nations' ${ }^{60}$ This contextualisation of the aforementioned trinity of rights chimes with the fact that they may be regarded as central to a liberal conception of environmental citizenship, such as that posited by Bell 61 who founds his view of what he prefers to term 'citizens of an environment' on a dual conception of a human right to 'have our basic needs met' and the [Rawlsian] 'fact of reasonable pluralism.' ${ }^{2}$ The former accounts for substantive entitlement, the latter he argues suggests:

...one conception that all reasonable citizens should accept for the purposes of a theory of political justice, namely, the nature and value of the environment is 'a subject about which there is reasonable disagreement'. ${ }^{63}$

This element of citizenship therefore accounts for the need for procedural rights, which, in addition to enjoying value in their own right, are required to support the (inevitable) contestation of substantive rights claims in practice. Drawing on this

58 'UNEP Welcomes Entry into Force of the Aarhus Convention' at http://www.unep.org/Documents. multilingual/Default.asp?DocumentID=224\&ArticleID=2950\&I=e $\mathrm{n}$ accessed 29 May 2014.

59 UNECE Convention on Access to Information Public Participation in Decision-making and Access to Justice in Environmental Matters at <http://www.unece.org/fileadmin/DAM/env/pp/documents/cep43e.pdf> accessed 29 May 2014.

60 Quoted in UNEP n 53.

${ }^{61}$ Bell, $\mathrm{n} 34$.

62 lbid 183.

63 Ibid 185. 
in the legal sphere (and disregarding the other social and political ways in which these may be made manifest), exercising environmental citizenship rights requires as a minimum the institution of a number of specific procedural rights. Building on Principle 10 of the Rio Declaration and its elaboration in the Aarhus Convention, chief amongst these are: access to information (which must be in such a form as to enlighten and empower rather than confuse and obfuscate); the opportunity to attempt to influence decision-making processes (requiring involvement at an early stage, while options are still open); and the capacity and ability to contest legally problematic outcomes.

Consideration of public participation in environmental law tends all too often to assume its beneficial qualities as a given ${ }^{64}$ and indeed they are difficult to gainsay, (other than on grounds of added expense and delay) ${ }^{65}$; it is much rarer to find discussion that points to its concrete contribution to decision-making. One notable exception is the work of the United Kingdom's Department of Environment, Transport and the Regions ${ }^{66}$ which promotes participation as having practical benefits in terms of the quality of the individual decision arrived at (ensuring that it is more fully informed, benefitting from public 'skills and enthusiasm' and first-hand knowledge $)^{67}$ and for the health of democracy more generally. Rather less predictably for a document emerging from a government department sponsored workshop, public participation is also characterised as a

\footnotetext{
${ }^{64}$ See Thomas C Beierle and David M Konisky 'Values, conflict, and trust in participatory environmental planning' Journal of Policy Analysis and Management, 19.4. 2000, pp 587-602. ${ }^{65}$ For an early but still cogent consideration of the costs associated with broader public participation in decision-making processes see Ernest Gellhorn 'Public participation in administrative proceedings' 81 Yale Law Journal 1971-72 359-404.

66 DETR: Public Participation in Making Local Environmental Decisions: The Aarhus Convention Newcastle Workshop Good Practice Handbook (DETR, London, 2000).

67 lbid, 11.
} 
moral duty that is incumbent on public authorities (as they work for the public and need to be informed about their wishes) but which also applies to individuals as: '[e]ach person has a stake in protecting and enhancing the environment ....' ${ }^{68}$ This attempt to combine state-based/top-down activity with public participation/bottom up approaches presents a concretisation of a core element of the theory of sustainable development and provides an example of attempting to re-fashion the decision-making paradigm. Its rationale lies in the novelty and complexity of what is at stake: '[S]olutions to achieve economic, social and environmental improvements at the same time will only be found if everyone is involved and if the discussion is open so that new ideas and approaches can be considered.' 69

5. Environmental (participation and substantive) rights In many ways the rise of procedural participation rights at Rio made perfect sense in practical terms as they were integral to sustainable development and a product of the WCED and UNCED procedures (see above) - but more than this, they fell fully formed into a convenient yet nonetheless erroneous tendency (that had begun to emerge in the 1980s) to conflate environmentalism and human rights activism. ${ }^{70}$ While there are undoubted synergies between the two areas, and where these occur they lend themselves very well to the pursuit of activism and legal claims through established human rights based approaches, the coincidence of human rights and environmental priorities is by no means a

\footnotetext{
68 Ibid.

69 lbid.

70 Ken Conca, 'Environmental Governance After Johannesburg: From Stalled Legalization to Environmental Human Rights' Journal of International Law and International Relations Vol 1 122-138 December 2005, at p131.
} 
given and the relationship between the two is often fraught and always complex. Nonetheless, in light of continued environmental degradation and an oft associated flagrant disregard for the human rights (of minorities and indigenous peoples in particular) and in the absence of productive international law engagement with many environmental problems that has been manifest as the momentum generated by the UNCED flagged, Conca suggests the rise of environmental human rights activism has filled the resulting lacuna. He argues that it suggests the possibility that: 'these contentious political episodes may be supplanting interstate bargaining as the primary motive force behind the further institutionalization of some form of global environmental governance. ${ }^{71}$ This probably overstates the case, given the difficulties in litigating environmental human rights claims (not least in respect of standing, causation and in many cases even justiciability) and the fact that it represents but one strand - albeit a high profile and innovative one - in a complex web of global/local and legal/political engagement with environmental issues. In any event, it seems likely that procedural human rights based environmental litigation will remain significant both in its own right and in the continued absence of an agreed, overarching, specific, substantive hard law ${ }^{72}$ environmental human right in international law in either human rights or environmental regimes. This is not to say that such a development is not potentially viable, but it would involve considerable practical and conceptual challenges. ${ }^{73}$ Thus, despite concentrated

\footnotetext{
$71 \mathrm{lbid}, 133$.

72 There are a number of recognised soft law international statements of an environmental right, variously framed, see, for example, Dinah Shelton, 'Human Rights and the Environment: What specific Environmental Rights have been Recognized?' (2007) 35 Den J of Int'l L \& Pol'y 129. ${ }^{73}$ See, for example, A. Boyle: 'Human Rights and the Environment: Where Next?' (2012) 23.3 European Journal of International Law 613.
} 
efforts by international institutions to push the substantive environmental right agenda forward, such as the UN Human Rights Council's lengthy involvement in this area, ${ }^{74}$ the concept has not yet gained substantial traction amongst states. In the absence of progress, vociferous NGO activism has emerged in this area, culminating in attempts under the auspices of the 'Stand Up For Your Rights' $^{\prime 75}$ initiative, to codify an environmental human right. Nonetheless there seems to be little or no realistic prospect of an overarching global substantive international environmental right emerging in the short to medium term. ${ }^{76}$ Indeed even the development of narrower substantive environmental rights such as the right to water, appear to be intractably mired in an international system that seems incapable of reaching agreement on them. ${ }^{77}$ Nonetheless, many and various environmental rights are now contained in regional international law instruments ${ }^{78}$ and increasingly in many state constitutions, ${ }^{79}$

\footnotetext{
${ }^{74}$ Ibid and UNHRC 'UN Human Rights Council (and its predecessor the Human Rights Commission)' at <http://www.righttoenvironment.org/default.asp?pid=87> accessed 04 February 2014.

75 Stand Up For Your Rights at <http://www.standupforyourrights.org/default.asp?pid=49> accessed 04 February 2014.

${ }^{76}$ This view is borne out by John Knox's work for the UNHRC mapping numerous specific substantive rights that pertain to the environment but also pointing to a continuing and significant lack of clarity in important areas, see A/HRC/25/53 Report of the Independent Expert on the issue of human rights obligations relating to the enjoyment of a safe, clean, healthy and sustainable environment, John H. Knox, 30 December 2013, at <http://www.ohchr.org/EN/HRBodies/HRC/RegularSessions/Session25/Pages/ListReports.aspx accessed 29 July 2014.

77 See Owen Mclntyre: 'The human right to water and reform of the Irish water sector' (2014) 5.1 Journal of Human Rights and the Environment, 74 at pp76-87.

${ }^{78}$ See, notably, explicit provision in Article 24 of The African Charter of Human and People's Rights 1981 at < http://www1.umn.edu/humanrts/instree/z1 afchar.htm> accessed 25 November 2013 and Article 11 of the additional protocol to the American Convention on Human Rights in the Area of Economic, Social and Cultural Rights 1988 at <http://www.oas.org/juridico/english/treaties/a-52.html> accessed 25 November 2013 and implicit coverage using other rights in the European Convention for the Protection of Human Rights and Fundamental Freedoms 1950, at

<http://www.echr.coe.int/Documents/Convention_ENG.pdf> accessed 25 November 2013 - see, for example, Karen Morrow, After the Honeymoon: The Uneasy Marriage of Human Rights and the Environment Under the European Convention on Human Rights and in UK Law Under the Human Rights Act 1998, (2013) 43 Revue générale de droit 317.
} 
and though these vary considerably in both their formulation and justiciability, they continue to fuel debate on further developing international environmental rights in like fashion.

While substantive international environmental rights remain problematic, the same is not true for procedural environmental rights of the type invoked under the Principle 10 triad. ${ }^{80}$ These tend to be less contentious, not least because (as noted above) it is possible to regard them less as a novel category of environmental rights, than as an application of well-established human rights in an environmental context. Procedural rights also appeal to states more than substantive rights as they tend, in guaranteeing process rather than outcome, to allow maximum room to manoeuvre. In any event, they play an important role in environmental issues at all levels. Hayward goes so far as to argue that procedural rights are 'superior' to substantive rights in the environmental sphere. ${ }^{81}$

While procedural rights are not exclusively applicable in environmental cases, nonetheless, they are arguably developing new, interesting and potential farreaching dimensions when employed in these contexts that can serve to augment the importance of the environment in decision-making processes that does have value in its own right.

\footnotetext{
79 See Christopher Jeffords, Constitutional Environmental Human Rights: A Descriptive Analysis of 142 National Constitutions, Human Rights Institute, the University of Connecticut Economic Rights Working Paper Series (2010) at <http://www.econ.uconn.edu/working/16. pdf >, accessed 21 October 2013.

80 Dinah Shelton and Alexandre Kiss: Judicial Handbook on Environmental Law (2005) UNEP at $<$ http://www.unep.org/environmentalgovernance/Portals/8/documents/JUDICIAL HBOOK ENV LAW.pdf>

${ }^{81}$ Tim Hayward, Constitutional Environmental Rights (OUP 2004).
} 
As a matter of principle, despite the very real difficulties that it presents, the search for a meaningful manifestation of a global over-arching substantive environmental right arguably remains a matter of the utmost and most profound necessity in the existentially crucial task of re-casting the Earth/human paradigm in a more sustainable guise. Nonetheless, procedural rights are of considerable utility in this regard, not least in light of present problems evident in domestic law in ascribing concrete content to a substantive environmental right that can render such claims difficult to litigate. However, it must be kept in mind that, while procedural rights-based claims may secure environmental issues their day in court, given their intrinsic focus on due process they do not necessarily secure environmentally desirable outcomes - they merely ensure that decisions arrived at are duly made.

6. Civil Society Participation in Sustainable Development between the UNCED and the UNCSD

The ongoing and thoroughgoing level of civil society engagement and participation in environmental law and policy processes initially mandated by Agenda 21 and fostered thereafter under the auspices of the UN Commission on Sustainable Development ${ }^{82}$ (CSD, a functional commission of the UN Economic and Social Council (ECOSOC) inaugurated after Rio) underlined the mainstreaming intent of the UNCED developments and generated considerable expectation. While far from perfect, ${ }^{83}$ as is to be expected in developing a new

\footnotetext{
${ }^{82}$ At <http://sustainabledevelopment.un.org/csd.html> accessed 06 May 2014.

${ }^{83}$ See, for example, Barbara Adams and Lou Pingeot, Strengthening Public Participation at the United Nations For Sustainable Development: Dialogue, Debate, Dissent, Deliberation, UN DESA / DSD Major Groups Programme 2013 at
} 
modality, the CSD did solid work as a 'pathfinder'84 in participatory sustainable development praxis, albeit not without some prompting from the UN General Assembly, ${ }^{85}$ in particular in sharing best practice and building stakeholder capacity. Its institutional profile was however comparatively low even within the UN and its work did not ultimately generate a great deal momentum in the sustainable development policy agenda. ${ }^{86}$

Nonetheless, operationalising the concept of sustainable development had created a practical need to and laid a conceptual foundation for expanding and refining participation in its areas of concern, and the CSD propagated a great deal of good practice in this regard in particular in the challenging area of forging links between hithertofore discrete bottom-up and top-down systems. Its work in this area, organising regular themed meetings and disseminating good practice, has arguably had important implications, commencing a slow ${ }^{87}$ but also profound re-shaping of this branch of the international polis and its culture. In a direct manifestation of this, UNEP also embraced the newlyprioritised participation culture fostered by the UNCED outcomes, stepping up its existing efforts in this regard and working with Agenda 21 major groups and

<http://www.globalpolicy.org/images/pdfs/images/pdfs/UNDESA_MGs_Report.pdf>Accessed 06 April 2014.

$84 \mathrm{lbid}$, at p8.

${ }^{85}$ A/RES/S-19/2, mandating strengthening CSD interaction with representatives of major groups, 1997.

${ }^{86}$ See, for example, Stine Madland Kaasa, The Commission on Sustainable Development: A Study of Institutional Design, Distribution of Capabilities and Entrepreneurial Leadership, Lysaker, Fridtjof Nansen Institute, 2005 at <http://www.fni.no/doc\&pdf/FNIR0505.pdfhttp://www.fni.no/doc\&pdf/FNI-R0505.pdf> accessed 15 April 2014.

87 See A/58/817, "We the Peoples: Civil Society, the United Nations and Global Governance: Report of the Panel of Eminent Persons on United Nations-Civil Society Relations," 11 June 2004 (colloquially referred to as the Cordoso report) for example, which pointed to limitations in the UN's practical engagement with civil society over a decade on from the UNCED. 
other stakeholders. ${ }^{88}$ UNEP's experience in this regard has enabled it to identify a number of practical benefits arising from the participatory approach in the sustainable development arena at an international level. These include allowing access to the various abilities of civil society groups to provide services; representation; advocacy and policy input; capacity building; and to carry out social functions. ${ }^{89}$ Furthermore, civil society participation is increasingly identified as a key element in fashioning 'sound environmental governance' through not only garnering wider support for decisions but also by opening up access to decision-making processes to improve transparency and foster accountability. ${ }^{90}$ Above all, in the sustainability context, UNEP views civil society participation as providing a specifically 'environmental' counterweight to the social and economic elements of the sustainability triad. ${ }^{91}$

\section{The UNCSD, participation and sustainable development}

Despite the promising start provided by the WCED and the UNCED, and incremental developments in the interim, by the advent of the United Nations Conference on Sustainable Development (the UNCSD), popularly known as 'Rio+20', it was universally acknowledged that progress on sustainable development had stalled. ${ }^{92}$ The conference outcome document, 'The Future We

\footnotetext{
88 UNEP 'Major Groups' at <http://www.unep.org/civilsociety/MajorGroups/tabid/52184/Default.aspx> accessed 07 May 2014. 89 UNEP 'Natural Allies: Engaging civil society in UNEP's work' (2nd edn.) Nairobi, UNEP, 2009 at <http://www.unep.org/civilsociety/Portals/24105/documents/publications/UNEP_NaturalAllies_June2009.pdf > accessed 07 May 2014 at $\mathrm{p} 13$.

$90 \mathrm{lbid}$ at $\mathrm{p} 16$.

91 lbid.

92 A/RES/6/288 'The Future We Want' at <http://www.uncsd2012.org/content/documents/727The\%20Future\%20We\%20Want\%2019\%20 June\%201230pm.pdf > accessed 30 April 2014 for example pointed to the need for
} 
Want', was at great pains to underline the collective nature of the endeavour to breathe new life into sustainability. Thus it took pains to underline its participatory credentials, even beginning its preamble by referring to not only the role of states and governments but also specifically to the '... full participation of civil society...93 in the process. The document also stated, underlining the great breadth of participation that this entails, that: '.. sustainable development must be inclusive and people-centred, benefiting and involving all people...'94 'The Future We Want' of course also pointed to its sustainability heritage, reaffirming past outcomes and agreements, including the Stockholm and Rio Declarations and Agenda $21 .{ }^{95}$ Crucially for current purposes the document also explicitly (re)embraced the participation agenda, devoting considerable discrete coverage to the issues that this raised. ${ }^{96}$ Significantly the document not only reiterated the existing approach, it also augmented it by adopting an expansive approach towards its future development stating that:

We underscore that broad public participation and access to information and judicial and administrative proceedings are essential to the promotion of sustainable development. Sustainable development requires the meaningful involvement and active participation of regional, national and subnational legislatures and judiciaries, and all major groups ... as well as other stakeholders .... .In this regard, we agree to

\footnotetext{
'...reinvigorating the global partnership for sustainable development ...' and to '...impart new momentum' to its pursuit at para 55.

93 Ibid, para 1.

$94 \mathrm{lbid}$, para 31.

$95 \mathrm{lbid}$, paras 14-16.

96 'The Future We Want' n 92 section C. Engaging Major Groups and other Stakeholders, paras 42-55.
} 
work more closely with the major groups and other stakeholders, and encourage their active participation, as appropriate, in processes that contribute to decision-making, planning and implementation of policies and programmes for sustainable development at all levels. ${ }^{97}$

'The Future We Want' acknowledged the key role played and to be played by civil society in facilitating public participation in sustainable development, noting its ability to contribute '.. diverse experience, expertise and capacity, especially in the area of analysis, the sharing of information and knowledge, promotion of dialogue and support of implementation of sustainable development'. 98 The document also underlined the conditions required to promote this wide-ranging civil society engagement including: improved access to information; effective capacity building; and viable and accessible information technology in enabling this. ${ }^{99}$

In a like vein, in terms of future institutional provision for sustainable development, where reform was very much the order of the day, 'The Future We Want' promised to:

Enhance the participation and effective engagement of civil society and other relevant stakeholders in the relevant international forums and, in this regard, promote transparency and broad public participation and partnerships to implement sustainable development. ${ }^{100}$

Following the UNCSD and building on the ongoing commitment to mainstreaming sustainable development expressed by the international

\footnotetext{
$97 \mathrm{lbid}$, para 43.

$98 \mathrm{lbid}$, para 53

99 lbid, para 44.

100 lbid, para 76(h).
} 
community and the adoption of a newly enhanced profile for it, a substantive reform process has begun. This is chiefly reflected in the replacement of the CSD with the High-Level Political Forum on Sustainable Development (HLPF) ${ }^{101}$ in 2013. On the one hand the HPLF sets out its stall as an intergovernmental forum much more clearly than was the case for the CSD which many in itself prove cause for concern, on the face of it running counter to the more catholic approach that it replaces. The HPLF promises to offer a much-needed more holistic and systemic consideration of sustainable development issues that has previously been the case. ${ }^{102}$ On the other hand the HLPF claims to build closely on what has gone before ${ }^{103}$ and aspires to continue the CSD's active engagement with major groups and (even more expansively given the perceived limitations of the major groups approach) ${ }^{104}$ other stakeholders. At the first meeting of the HLPF in 2013, coverage of the sustainable development agenda ${ }^{105}$ to a degree echoed that at the UNCSD itself, with economic and to a lesser extent social priorities placed strongly to the fore. ${ }^{106}$ Distinctively though on this occasion environmental concerns formed a prominent refrain and participants called for the HLPF to develop '....a

\footnotetext{
101 Set up following Rio 2012 at <http://sustainabledevelopment.un.org/index.php?menu=1556> accessed 06 April 2014.

${ }_{102} A / 68 / 588$, 'Summary of the first meeting of the high-level political forum on sustainable development' at http://www.un.org/ga/search/view_doc.asp?symbol=A/68/588\&Lang=E accessed 30 May 2014.

103 See A/67/L.72, 'Format and organizational aspects of the high level political forum on sustainable development', Draft Resolution, 27 June 2013. See also Steven Bernstein, 'The Role and Place of the High-Level Political Forum in Strengthening the Global Institutional Framework for Sustainable Development' 2013 at <http://sustainabledevelopment.un.org/content/documents/2331Bernstein\%20study\%20on\%20 HLPF.pdf>_accessed 06 May 2014.

${ }^{104}$ Adams and Pingeot, $\mathrm{n} 83$.

${ }^{105} \mathrm{~A} / 68 / 588$ n 105 para 1.

106 This reflected the characterisation of sustainable development in the UNCSD process, see Karen Morrow 'Rio +20, the Green Economy and Re-orienting Sustainable Development' 14.4 Environmental Law Review 2012 pp 279-297.
} 
coherent approach that integrates in a balanced manner the three dimensions of sustainable development. ${ }^{107}$ Coverage of the participation agenda too gave some grounds for optimism, with major groups and other stakeholders among the active participants at the event ${ }^{108}$ and the encouraging and expansive statement that:

... enhanced and coordinated participation of major groups and other relevant stakeholders such as private philanthropic organizations, educational and academic entities, persons with disabilities, volunteer groups and other stakeholders is essential to the success of the highlevel political forum and of the post-2015 development agenda. ${ }^{109}$

\section{The UNCED/UNCSD's participation legacy?}

The UNCED and UNCSD processes and outcomes relating to broadening participation in sustainable development and by dint of this environmental governance can be viewed as setting positive precedents for invoking change but they do not by any means provide a template for substantive progress. While their combined effect has the potential to actualise a fundamental alteration in the way in which the business of international environmental law and policy is done, doubtless of enormous significance in principle, to date progress in practice has been at best limited. Together, if fully pursued, they could mainstream the nascent re-fashioning of the very nature of the international polis, augmenting the extension of its reach as demonstrated across the range of the WCED and UNCED preparatory processes discussed

\footnotetext{
107 A/68/588 n 105 para 21.

108 Ibid para 1.

109 lbid para 11.
} 
above. The UNCED and UNCSD outcome documents endorse a conception of an active international community that extends well beyond traditional state and intergovernmental actors; giving non-state actors (initially in the guise of the nine Agenda 21 major groups referred to above and latterly reaching more widely still) a more marked, extensive and above all constant role ${ }^{110}$ than had previously been the case in international environmental law. The motivation for this shift first in attitude and in the longer term behaviour towards non-state actors lies not in states embracing a new pluralism in international environmental affairs; rather it was necessitated by one of the core characteristics of the concept of sustainable development which, as acknowledged in the WCED process, discussed above, is as dependant on grassroots buy-in and bottom-up action as it is on statecraft. Thus, from the outset, advancing sustainability has been understood as requiring not only the engagement of states that is the traditional province of international law, but also the active involvement of civil society, secured in large part by expanding rights-based participation into a new realm. By signing up to the Rio Declaration and Agenda 21, states were effectively 'buying in' to this approach, though perhaps not fully taking on board its implications at the time. This would seem to be borne out by the effective relegation of much civil society involvement in the sustainable development agenda into the sphere of the CSD in the two decades after the UNCED which effectively enabled the UN to 'tick the participation box' while confining participation to an institutional by-water. Belatedly, the post UNCSD process suggests that the fuller implications of a viable sustainability

\footnotetext{
${ }^{110}$ Non-state actors had already at this point played a significant role in a variety of international law contexts, for example in human rights and gender equality but their role in the emerging environmental sphere had been considerably less prominent.
} 
agenda and in particular in the conception and operationalization of sustainable development goals that are likely to be the province of the HLPF are beginning to be more fully appreciated - though it is too soon to tell if this will in fact lead to substantive further development of the participation agenda or mere lipservice towards it and a retrograde return to a state-centrism that is bound to fail to deliver on sustainability.

\section{$\underline{\text { Conclusion }}$}

It can be argued that, for all of its limitations, the expansive participatory approach to sustainability pioneered by the WCED and endorsed at the UNCED, did indeed sow what may well prove to be, in the words of the poet Simon Armitage: 'The seeds of the world for the world after this', ${ }^{111}$ by laying a foundation for innovative modes of expanded societal engagement in international environmental law and policy. However, it remains to be seen whether these seeds will be better nurtured in the wake of the UNCSD than has been the case hithertofore. That they should be is imperative as a response to the 'new world' that we now seem set on an inexorable course toward; one in which we are exceeding/approaching crucial planetary boundaries that make it incumbent on humanity to make sustainable development a way of life rather than a mere catchphrase. ${ }^{112}$ Whether this will actually be achieved remains to be seen.

\footnotetext{
111 Simon Armitage, Climate of Change, screenplay, 2008

112 J Rockström, W Steffen, K Noone, A Persson, FS Chapin III, E Lambin, TM Lenton, M Scheffer, C Folke, H Schellnhuber, B Nykvist, CA De Wit, T Hughes, S van der Leeuw, H Rodhe, S Sörlin, P K Snyder, R Costanza, U Svedin, M Falkenmark, L Karlberg, R W Corell, V J Fabry, J Hansen, B Walker, D Liverman, K Richardson, P Crutzen and J Foley, 'Planetary Boundaries: Exploring the Safe Operating Space for Humanity' (2009) 14(2) Ecology and Society 32 <http://www.ecologyandsociety.org/vol14/iss2/art32/> accessed 9 May 2014.
} 